www.jmscr.igmpublication.org

Impact Factor 5.244

Index Copernicus Value: 83.27

ISSN (e)-2347-176x ISSN (p) 2455-0450

crossref DOI:_http://dx.doi.org/10.18535/jmscr/v4i8.82

Journal Of Medical Science And Clinical Research

IGM Publication

An official Publication of IGM Publication

\title{
Chemokines Profile in Patients with Graves Diseases in Comparison to Nonautoimmune Hyperthyroidism in Al-Najaf Province
}

\author{
Authors \\ Dr Kareemthamir Mashkoor Al-Kaabi ${ }^{1}$, Dr Salmanazizal. Jibori ${ }^{2}$, \\ Abdullah Turki Al-Ziadi ${ }^{3}$ \\ ${ }^{1,2}$ Prof Medical Microbiology, Medicine College, Kufa University \\ ${ }^{3} \mathrm{MSc}$, Student Microbiology Department, Medicine College, Kufa University

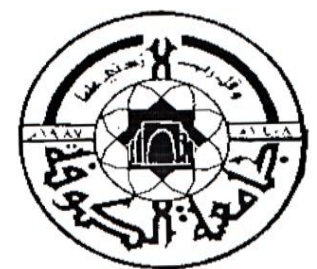 \\ Republic of Iraq, Ministry Of Higher Education and Scientific Research \\ University of Kufa, College of Medicine
}

\section{Introduction}

Graves' disease (GD), a form of hyperthryroidism (overactive thyroid gland), typified by auto antibodies directed against the thyroid stimulating hormone receptor (TSHR), Thyroid peroxidase (TPO) and thyroglobulin (Tg) (Hammerstad and tomer, 2015; Giménez-Barcons et al., 2015).

The presence of thyroid autoantibodies substantially contributes to the pathogenesis of a number of thyroid disorders, such as Hashimoto's thyroiditis, primary myxedema and Graves' disease (Xander et al., 2012). They are also present in a smaller percentage of sera from other non- autoimmune thyroid disorders. Thyroid autoantibodies in autoimmune thyroid diseases have been reported to range from $1-40 \%$ but its prevalence in non-autoimmune diseases is unknown (Elmugadam et al., 2014).

Autoimmune thyroid Graves' disease is one of the most common autoimmune disease (AID), affecting 13 million people and targeting women seven times as often as men. It most often affects young to middle-aged adults but can occur at all ages. (Vos et al.,2009; Utiger,2015).

Thyrotropin receptor antibodies (TRAb) exist as stimulating antibodies in 95-96\% of subjects with Graves' disease although only some can demonstrate their functional characteristics (Zöphel et al., 2010). The clinical features of Graves' hyperthyroidism occur when stimulating TRAb predominate But the relationship of TRAb to clinical phenotype and outcome is not clear when current assay methods are used

The course of thyroid autoimmune diseases is associated with the inflow of lymphocytes to the thyroid gland and with the expression of anti-TSH receptor, anti-thyroglobulin and antithyroid peroxidase antibodies. (Rapoport B, Chazenbalk 1998 ) 
Chemokines (CXCL10) plays an important role in the initial phases of Graves' disease (GD) and autoimmune thyroiditis (AT); however, until now, CXCL10 serum levels (sCXCL10) in patients with GD have never been evaluated in relation to thyroid function and treatment.

Graves' disease (GD) is a common autoimmune disease involving the thyroid gland. The altered balance of pro- and anti-inflammatory cytokines plays an important role in the pathogenesis of GD. Chemokine (C-C motif) ligand 20 (CCL20) is important for interleukin-17 (IL-17) signal activation and a potent chemo attractant for Th17 cells.(Planck T., 2010).

\section{1) Aim of the study}

- The study was aimed to evaluate the impact auto-immune thyroid graves disease on the circulating level of Chemokines: CCL10.CCL20. And comparison with other non-autoimmune hyperthyroidism in AL-Najaf province.

\section{2) Objectives:}

A. Measurement T3, T4 and TSH hormones.

B. Evaluation of Anti-TSHR-antibody "Anti-TSHR Abs

C. Estimation Anti-thyroid peroxidase antigen antibody "Anti-TPO Ab".

D. Evaluation chemokines (CCL10 and CCL20)

\section{Material and method}

\section{2-1- Study Population}

\subsubsection{Patients}

Included patients were newly diagnosed with thyrotoxicosis (with increased in T3 and/or T4 and decrease in TSH) "hyperthyroidism". Whole blood samples were collected from 74 cases in Najaf/Iraq, Out of the 74 hyperthyroidism patients, there were 65 females and 9 males, the patients age range was 20-50 years.

Hyperthyroidism patients were subdivided into two groups, including: Autoimmune hyperthyroidism "Graves' disease" patients group and Non-autoimmune hyperthyroidism patients group, by using Anti-TSHR Abs and Anti-TPO Abs.

\subsubsection{Control}

Nineteen healthy control groups who had no history or clinical evidence of hyperthyroidism or any chronic disease.

Exclusion Criteria: All patients with hyperthyroidism under treatment and pregnant women were excluded from the study. Study Parameters: All suspected hyperthyroidism patients and control group subjected to following immunological and hormonal studies:

A- Hormonal Estimation, including: T3, T4 and TSH Hormones.

B-Immunological Studies, including:

1- Anti-TSHR antibody "Anti-TSHR Abs".

2- Anti-thyroid peroxidase antibody "Anti-TPO Abs".

D- Chemkines (CCL10 and CCL20) estimation in serum of study group.

\section{3- Collection of Samples:}

Five $\mathrm{ml}$ of the whole blood were obtained by venipuncture from all study. 
2.4 Materials

Table (2-1) Kit and Antisera:

\begin{tabular}{|l|l|}
\hline \multicolumn{1}{|c|}{ Name of Kit } & Company \\
\hline TSH Receptor-Antibodies ELISA Kit & Human/ Germany \\
\hline Thyroidal Peroxidase-Ab (TPO-Ab) & Demeditec/Germany Inc./USA \\
\hline Thyrotropin (TSH) Test System ELISA Kit & Monobind Inc./USA \\
\hline Total Triiodothyronine (tT3) ELISA Kit & Monobind Inc./USA \\
\hline Total Thyroxine (tT4) ELISA Kit & Monobind Inc./USA \\
\hline Human CCL 10 ELISA Kit & eBioscience, USA \\
\hline Human CCL20 ELISA Kit & eBioscience, USA \\
\hline
\end{tabular}

\subsection{Methods:}

\subsubsection{Hormonal Tests:}

\subsubsection{Total Triiodothyronine (tT3) Hormone Assay:}

Total Triiodothyronine (tT3) ELISA kit were used for measurement of serum Triiodothyronine concentration in all studied groups. It is generally regarded as a valuable tool in the diagnosis of thyroid dysfunction (Chopra et al., 1971a)

\subsubsection{2- Total Thyroxine (tT4) Hormone Assay:}

Total Thyroxine (tT4) ELISA kit were used for measurement of serum Thyroxine concentration in all studied groups. It is generally regarded as an important in-vitro diagnostic test for assessing thyroid function (Chopra et al., 1971b).

\subsubsection{Thyrotropin (TSH) Hormone Assay:}

Thyrotropin (TSH) ELISA kit were used for measurement of the serum concentration of thyrotropin (TSH), a glycoprotein with a molecule weight of 28.000 Daltons and secreted from the anterior pituitary. It is generally regarded as the most sensitive indicator available for the diagnosis of primary and secondary (pituitary) hypothyroidism (Hopton and Harrap, 1986).

\subsubsection{Immunological Test:}

\subsubsection{Anti-TSH Receptor Antibodies Assay:}

TSH Receptor-Antibodies ELISA kit were used for the quantitative measurement of autoantibodies against TSH receptor in human serum. The assay is intended for in vitro diagnostic use only as an aid in the diagnosis of Graves' disease (Kamijo, 2003).

\subsubsection{Thyroidal Peroxidase- Abs (TPO-Abs) Assay:}

Thyroidal Peroxidase- Abs (TPO-Abs) ELISA kit was used for the quantitative measurement of IgG class auto antibodies against thyroid peroxidase (TPO) in human serum or plasma (Ruf et al., 1988).

\subsubsection{C-X-C motif chemokine 10 (CXCL10) :}

\section{A-Principle of the assay:}

This assay employs the quantitative sandwich enzyme immunoassay technique. A monoclonal antibody specific for IP-10 has been pre-coated onto a microplate. Standards and samples are pipetted into the wells and any IP-10 present is bound by the immobilized antibody. After washing away any unbound substances, an enzyme-linked polyclonal antibody specific for IP-10 is added to the wells. Following a wash to remove any unbound antibody-enzyme reagent, a substrate solution is added to the wells and color develops in proportion to the amount of IP-10 bound in the initial step. The color development is stopped and the intensity of the color is measured.

\subsubsection{C-X-C motif chemokine 20 (CXCL20) :}

\section{A-Assay principle:}

The Human CCL20 ELISA (Enzyme-Linked Immunosorbent Assay) kit is an in vitro enzyme-linked immunosorbent assay for the quantitative measurement of Human CCL20 in Cell Culture Supernatants, 
Serum, Plasma. This assay employs an antibody specific for Human CCL20 coated on a 96-well plate. Standards and samples are pipetted into the wells and CCL20 present in a sample is bound to the wells by the immobilized antibody. The wells are washed and biotinylated anti-Human CCL20 antibody is added. After washing away unbound biotinylated antibody, HRP-conjugated streptavidin is pipetted to the wells. The wells are again washed, a TMB substrate solution is added to the wells and color develops in proportion to the amount of CCL20 bound. The Stop Solution changes the color from blue to yellow, and the intensity of the color is measured at $450 \mathrm{~nm}$.

\section{3- Results and discussions}

3.1 Dermographical Study:

\subsubsection{Age distribution:}

Table: (3-1) Studied groups according to age.

\begin{tabular}{|l|c|c|c|c|}
\hline Parameter & $\begin{array}{c}\text { Graves disease } \\
\mathbf{n = 5 7}(\mathbf{G 1})\end{array}$ & $\begin{array}{c}\text { Non-autoimmune } \\
\text { hyperthyroidism } \\
\mathbf{n = 1 7}(\mathbf{G 2})\end{array}$ & $\begin{array}{c}\text { Control } \\
\mathbf{n = 1 9} \\
\mathbf{( G 3 )}\end{array}$ & P value \\
\hline Age/years & $37.8 \pm 7.9$ & $35.8 \pm 9.7$ & $34.5 \pm 7.5$ & 0.287 \\
\hline
\end{tabular}

A total of 93 subjects were included in the study, 57 of them with Graves disease (group 1), 17 nonautoimmune hyperthyroidism (group 2) and 19 healthy controls (group 3). The mean age of group 1 is $37.8 \pm 7.9$ years while group 2 is $35.8 \pm 9.7$ and that of group 3 is $34.5 \pm 7.5$ years with no significant difference between groups.

Table (3-2) Association between age and different study groups

\begin{tabular}{|c|c|c|c|c|c|}
\hline \multirow{2}{*}{ Age/ years } & \multicolumn{3}{|c|}{ Groups } & \multirow{2}{*}{ Total } & \multirow{2}{*}{$\mathrm{P}$ value } \\
\hline & Graves disease & Non-autoimmune hyperthyroidism & Control & & \\
\hline \multirow{2}{*}{$20-25$} & 4 & 2 & 1 & 7 & \multirow{12}{*}{0.709} \\
\hline & $57.1 \%$ & $28.6 \%$ & $14.3 \%$ & $100.0 \%$ & \\
\hline \multirow{2}{*}{$26-30$} & 10 & 6 & 6 & 22 & \\
\hline & $45.5 \%$ & $27.3 \%$ & $27.3 \%$ & $100.0 \%$ & \\
\hline \multirow{2}{*}{$31-35$} & 7 & $\overline{0}$ & 3 & 10 & \\
\hline & $70.0 \%$ & $0.0 \%$ & $30.0 \%$ & $100.0 \%$ & \\
\hline \multirow{2}{*}{$36-40$} & 15 & 3 & 4 & 22 & \\
\hline & $68.2 \%$ & $13.6 \%$ & $18.2 \%$ & $100.0 \%$ & \\
\hline \multirow{2}{*}{$41-45$} & 11 & 2 & 3 & 16 & \\
\hline & $68.8 \%$ & $12.5 \%$ & $18.8 \%$ & $100.0 \%$ & \\
\hline \multirow{2}{*}{$>45$} & 10 & 4 & 2 & 16 & \\
\hline & $62.5 \%$ & $25.0 \%$ & $12.5 \%$ & $100.0 \%$ & \\
\hline \multirow{2}{*}{ Total } & 57 & 17 & 19 & 93 & \\
\hline & $61.3 \%$ & $18.3 \%$ & $20.4 \%$ & $100.0 \%$ & \\
\hline
\end{tabular}

The current study revealed that the majority of GD patients were at age group (36-40) years. Although GD may affect anyone, the prevalence was highest in those subjects aged 40 years, and this result was completely compatible with Carlé et al., 2013 whose findings were confirmed in multivariate models reporting age as a significant predictor for referral in GD patients, among referred hyperthyroid patients, those aged up to 40 years (68.8\%), Graves' disease was more common among women in/and before the age of 40 year $(27,56 \%$ ) (Carlé et al., 2013). Also the presented study was agreed with a recent study in Iraq, by (AL-Gazally et al., 2013; AL-Fatlawy, 2014), who found that the incidence of AITD "GD" was higher in (36-45) year's age groups. Similar observation was reported by (Elmugadam et al., 2014), from AL-Sudan, he presented that the age at onset of Graves' disease was in the range (24-58) years. This observation also was in agreement with Brix et al., (1998) who stated that, a family history of thyroid disease can be obtained in up to $50 \%$ of patients with GD and family studies have repeatedly demonstrated a familial aggregation of GD. 
The current study was not in agreement with that of, Mahdi, (2014) who reported that the range of GD patient's age was (40 and 60) years. AL-Bustany, (2011), found that the age icidence of the patients with thyrotoxicosis was from (16 to 75 ) years and the mean age affected was a rounded 43 years age. This variation in results may be due to sample size in addition to difference populations. Regarding the mean age of patients, in this study (37.8 \pm 7.9$)$ years was reported in GD patients. This result was agreed with Elfadil et al.,(2014) who reported that the mean age of patients with hyperthyroidism without graves' disease was (35.8 \pm 9.7$)$ years, while the mean age of patient with graves' disease was (37.8 \pm 7.9$)$ years, and control group was (34.5 \pm 7.5$)$ years, p. value 0.287. Similar observation was reported by Al-Gazally et al., (2014), who

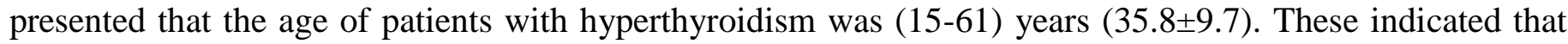
thyroid disorder may occur at any age, also these results were agreed with Kadhum and Hassan, (2014), who showed that the ratio of incidence was increased in females compared with males in all age groups.

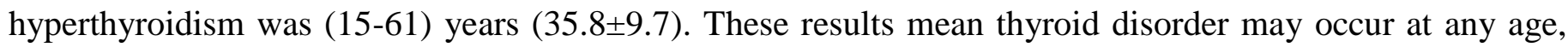
and these results were agreed with Kadhum and Hassan, (2014), they showed that the ratio of incidence was increased in females compared with males in all age groups.

The lowest mean of age among Iraq patients probably was due to the fact that the life spans of Iraqi patients were lower than that of European population. In addition the lower mean of age cumulative among patient with Graves' hyperthyroidism patients may be due to cumulative effects of environmental, psychological, and stress.

Age has consistently been observed as a significant modulating factor, so the current study demonstrated there was no significant difference between Graves' disease group, non-autoimmune hyperthyroidism group and healthy group regarding age $(\mathrm{P}=0.709)$ Table (3-2), Also this result was similar to other studies reported by (Vanderpump et al., 1995; Hollowell et al., 2002 and Zimmerman, 2009), and also compatible with that stated by (Vanderpump, 2011), who mentioned that the peak age specific occurrence of Graves' disease was between 20 and 49 years. And the prevalence was highest in those subjects aged (20-39)years and those aged $>79$ years.

Also showed that group (36 to 40) years was the most vulnerable age group to Graves' disease $(n=15)$, recording (68.2\%), comparison with non-autoimmune hyperthyroidism $(n=3)(13.6 \%)$.Although no significant difference in age between auto-immune Graves disease and non-auto-immune hyperthyroidism. Majority of the patients with Graves disease in the study were between (36 - 40) year about $68.2 \%$ and (2630) year about $27.3 \%$ in non-autoimmune hyperthyroidism. Regarding the mean age of patients ,in this study (37.8+- 7.9) year was reported in Graves disease patients this result was agree with (Elfadilet,al2014) who reported the mean age of Graves disease (34.8+-11.29)year and hyperthyroidism non graves disease (33.22+-10.04) year.

\subsubsection{Sex distribution}

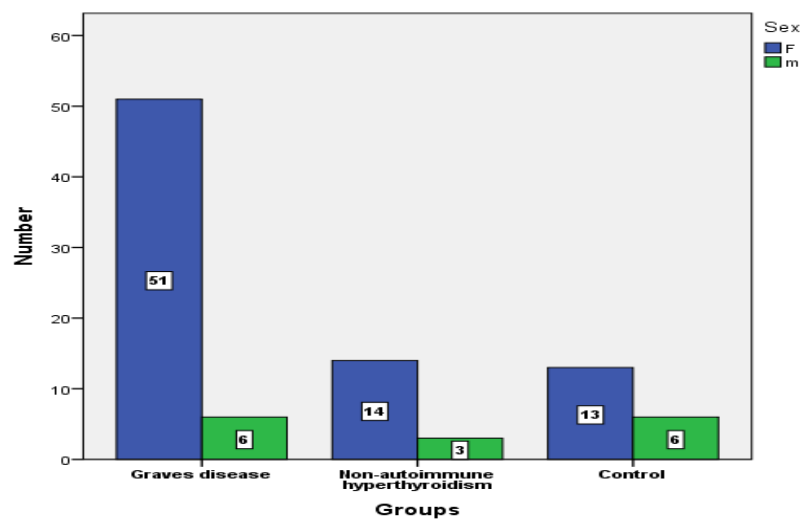

Figure (3-1) Gender distribution of the studied groups. 
A total of 57 patients with Graves' disease were enrolled in this study, 51 patients $(89.4 \%)$ were females and 6 patients $(10.6 \%)$ were males, In spite of the female sex was predominant among Graves' disease patients there was no significant difference between studied groups at $\mathrm{P}$ value $>0.05$ Whill the total of non autoimmune Graves disease in this study 17 patient. 13 patient (82.4\%) were female and 3 patient (17.6\%) male. ( $n=74)$ with female: male ratio 8.5:1. Many study reported that the incidence of GD in women higher than in men, with a varying sex-ratio (Fair weather, 2007; Kumar et al., 2013 and Elmugadam et al., 2014). Thyroid disorders are prevalent worldwide, especially in women, and this is associated with sex hormones imbalance such as estrogen hormone, which is normally elevated in females during puberty and pregnancy and the X chromosome which affect the thyroid and immune system (Lichiardopol and Mota, 2009).

The female: male ratio among GD patients in this study was in agreement with previous local studies in Iraq (4:1 and 2:1) (AL-Bustany, 2011; Al-Gazally et al., 2013 and AL-Fatlawi, 2014). However, our results were a comparable to that of the other studies (Akbar et al., 2000; Vita et al., 2009). These variations may be due to sample size in addition to different circumstances and times of sample collection besides different populations.

However, Women are known to respond to infection, vaccination, and trauma with increased antibody production and a more $\mathrm{T}$ helper Th2-predominant immune response, whereas a Th1 response and inflammation are usually more severe in men. Autoimmune diseases that are more prevalent in males usually manifest clinically before age 50 years and are characterized by acute inflammation, the appearance of auto antibodies, and a pro inflammatory Th1 immune response. In contrast, female-predominant autoimmune diseases that manifest during the acute phase, such as Graves' disease and systemic lupus erythematosus, are diseases with a known antibody-mediated pathology. Autoimmune diseases increments in females that appear clinically past age 50 are associated with a chronic, fibrotic Th2-mediated pathology, (Frisancho-Kiss and Rose, 2008).

The current study show that the presence o auto-immune Graves disease affected by gender although the higher percentage $89.4 \%$ of patient positive auto-antibodies in these study were female.

This might be due to fact that auto-immune disease ara more common in female than male the cause for this difference would be the sex hormones, female might respond more to conventional age due to sex hormones (Denmas, 1991)

\section{3-2.Hormonal analysis and graves disease}

Table(3-3) Comparison between groups in thyroid hormones(T3,T4 And TSH).

\begin{tabular}{|l|l|l|l|}
\hline Variables & Graves disease $(\mathbf{n}=\mathbf{5 7})$ & Non autoimmune $(\mathbf{n}=\mathbf{1 7})$ & Control $(\mathbf{n}=\mathbf{1 9})$ \\
\hline T3 ng/ml & $4.418 \pm 0.84$ & $2.11 \pm 0.603^{*}$ & $1.05 \pm 0.072^{*} \#$ \\
\hline T4 ng/ml & $21.25 \pm 2.303$ & $15.72 \pm 3.58^{*}$ & $8.36 \pm 0.617^{*} \#$ \\
\hline TSH ng/ml & $0.074 \pm 0.034$ & $0.63 \pm 0.427^{*}$ & $1.54 \pm 0.501^{*} \#$ \\
\hline
\end{tabular}

*significant vs Graves disease \#significant vs Non autoimmune

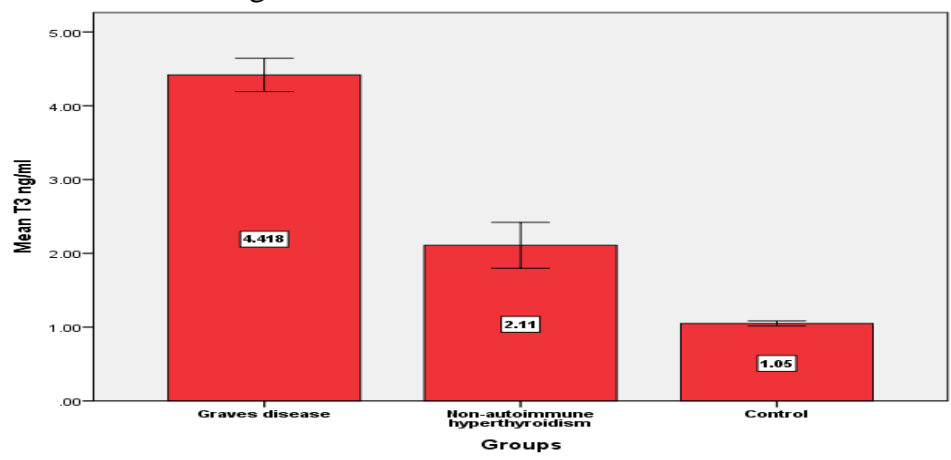

Figure (3-2) T3 level in different study groups.

$* *=$ highly significant $(\mathrm{P}<0.01)$ 


\section{LSD test: Showed significant difference between all studied groups.}

The level of T3 hormone among studied groups showed in Fig: (4-2), which revealed that the highest level of T3 hormone was among the GD patients $(4.418 \pm 0.84)$ while in non-autoimmune hyperthyroidism groups were $(2.11 \pm 0.603)$ and $(1.05 \pm 0.072)$ with healthy control groups. These results explain a significant differences $(\mathrm{P}<0.01)$, were observed in $\mathrm{T} 3$ hormone levels among studied groups.

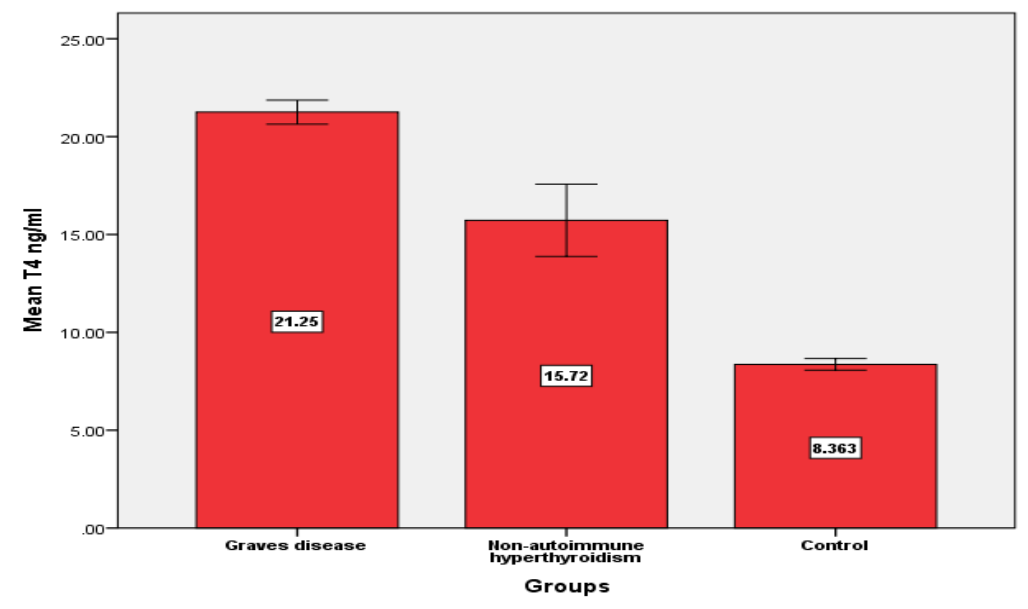

Figure (3-3) T4 level in different study groups.

The present study revealed that the highest level of T4 hormone was found among the sera of Graves' disease patients $(21.25 \pm 2.303)$ as compared with non-autoimmune hyperthyroidism patients $(15.72 \pm$ $3.58)$ and healthy control groups $(8.36 \pm 0.617)$, with a highly significant differences among studied groups $(\mathrm{P}<0.01)$.

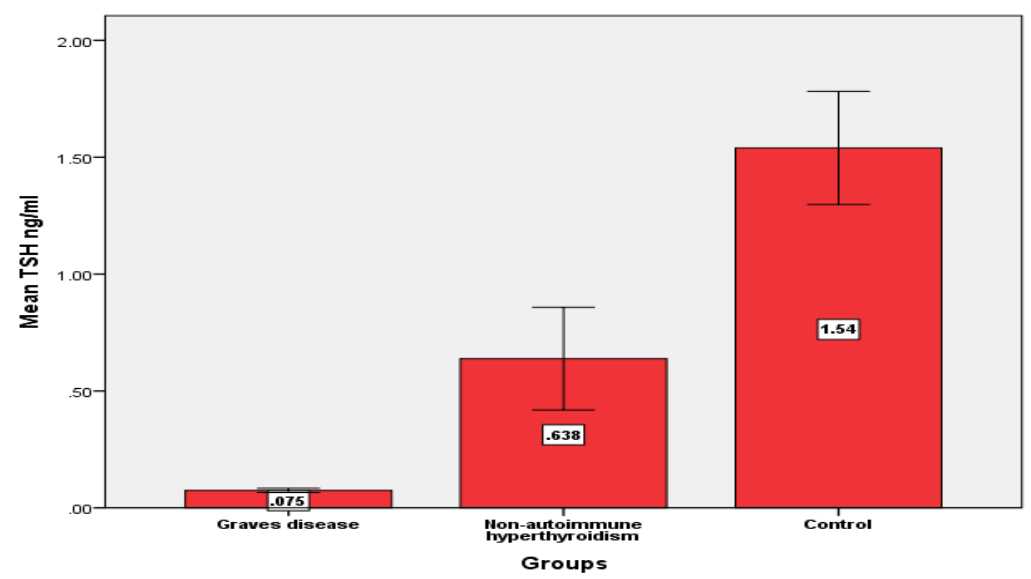

Figure(3-4) Serum TSH level in different study groups.

Evaluation of Serum TSH Levels among Studied Groups: The results which presented in Fig: (4-3) were showed that a highly significant difference $(\mathrm{P}<0.01)$ between Graves' disease patients $(0.074 \pm 0.034)$ and patients with non-autoimmune hyperthyroidism groups $(0.63 \pm 0.427)$ and $(1.54 \pm 0.501)$ with healthy control.

Table (4-3) shows there is significant difference between group 2 and 3 in level of T3, T4 and TSH. The results obtained from table (3-3), figures(3-2),(3-3),(3-4) showed highly significant increase levels of T3 and T4 associated with highly significant decrease of TSH levels in both males and females for patients with Graves' disease and non-autoimmune hyperthyroidism in comparison with control subjects. The explanation for this result that is an excess production of T3 and T4 accompanied by low level of TSH was believed due to production of auto antibodies the source of these antibodies is immune competent plasma cells, the antibodies bind with TSHR to initiate and increase T3 and T4 synthesis and production regardless of decrease level of TSH by negative feedback mechanism which exerted by T3 and T4 on pituitary and hypothalamic axis (Al-Gazally et al., 2014). The level of T4, being an indicator of the severity of 
thyrotoxicosis, was also correlated with the Th1/Th2 and pro inflammatory cytokines in Graves' disease patients (Hollowell et al., 2002; Vanderpump, 2011). Choksi et al., (2003) and Devi et al., (2012), revealed that hyperthyroidism was increased the effectiveness of tissue within the thyroid gland, which resulting hyperactivity in the production of one or both thyroid hormones (T3 and T4), and they reported that most causes of hyperthyroidism were Graves' disease (GD). Therefore, a total T3/T4 ratio and TSH value, is a useful parameter for the rapid differentiation of Graves' disease (Yanagisawa et al., 2005; Carole, 2013). Among these hormones, serum TSH concentrations are considered the most reliable indicator of thyroid function abnormalities, because, the log/linear TSH/FT4 relationship dictates that an altered TSH will be the first abnormality to appear - as soon as the pituitary registers that FT4 has changed from its geneticallydetermined set point for that particular individual (Garber et al., 2012). However, small changes in T4 concentration will provoke very large changes in serum TSH. The setting of the TSH reference range is critical for detecting mild (subclinical) hypo- or hyperthyroidism. Therefore, TSH measurement was appeared to be the first choice in selecting the hormone determination (Soldin et al., 2013)

Individuals with the persistently undetectable TSH but normal thyroid hormones (in the absence of pituitary disease and drug effects) are said to have subclinical hyperthyroidism and need future investigation, there is little clear evidence to guide treatment in this situation. In the presence of clear extrathyroidal signs of Graves' disease (e.g, proptosis, dermopathy), no further testing beyond thyroid hormones and TSH is necessary. In the absence of these features, an attempt to secure an etiological diagnosis should be made (Weetman, 2007).

\subsection{Immunological analysis and graves disease.}

Table(3-4) Comparison between Graves disease, nonautoimmune thyroiditis and control group regarding in different variables of Immunological parameters.

\begin{tabular}{|c|c|c|c|}
\hline Variables & Graves disease $(\mathbf{n}=57)$ & Non autoimmune $(n=17)$ & $\begin{array}{l}\text { Control } \\
(n=19)\end{array}$ \\
\hline Anti-TPO IU/ml & $332.05 \pm 45.8$ & $25.047 \pm 6.31 *$ & $10.52 \pm 1.185^{*}$ \\
\hline Anti-TSH receptor Ab. IU/ml & $24.965 \pm 6.048$ & $0.004 \pm 0.0019 *$ & $0.018 \pm 0.004 *$ \\
\hline
\end{tabular}

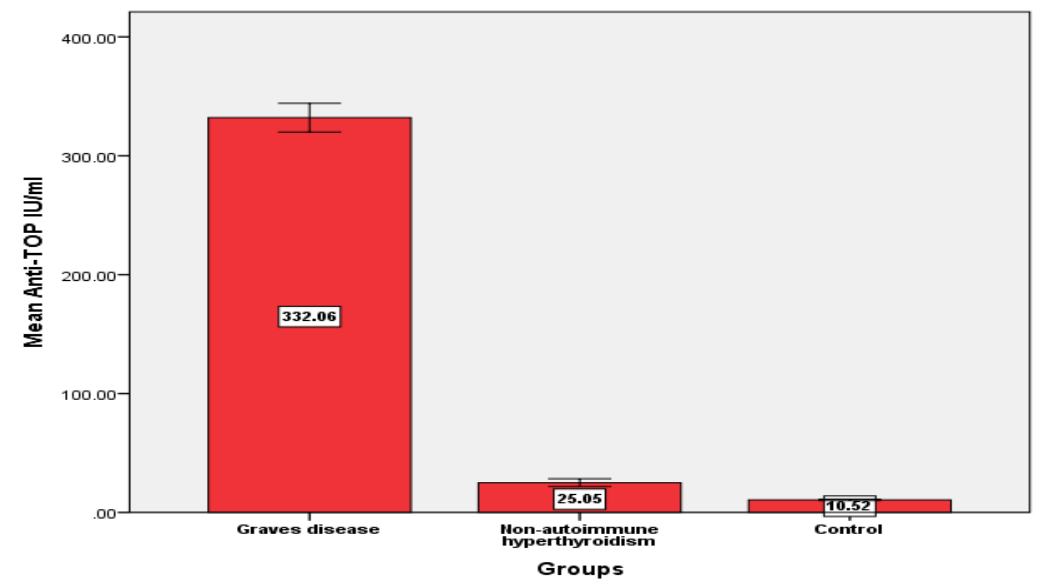

Figure (3-5) Anti TPO level in different study groups.

\section{Estimation of serum anti-TPO abs among studied groups:}

The results in Table (3-4) showed highly significant difference $(\mathrm{P}<0.01)$ between Graves' disease patients, non-autoimmune hyperthyroidism patients and healthy control groups $(332.05 \pm 45.8,25.047 \pm 6.31$ and $10.52 \pm 1.185$, respectively). Also in table (3-4) showed that the serum levels of thyroidal peroxidase (TPO) autoantibodies were high significantly increased in patients with Graves' disease $(n=57)(61.3 \%)$, from a 
total number (93) patients of Graves' hyperthyroidism, as compared with other group depended on Cut-off value.

In the table (3-4), the results revealed significant differences in level of auto- antibodies TPO to the thyroid gland in patients with Graves' hyperthyroidism (70.4\%) as compared with non-autoimmune hyperthyroidism and healthy control group $(0.0 \%)$. And these results were in agreement with a recent local study in Iraq by (AL-Fatlawi, 2014; Kadhum and Hassan, 2014). Other studied in Sudan by (Elmugadam et al., 2014), who presented that the Anti-TPO antibody was positive in $66.7 \%$ of Graves' disease patients compared to $5 \%$ of control group, and $17.5 \%$ in patients with non-autoimmune hyperthyroidism disease. Many studied appeared that the TPO-Abs were significantly associated with auto-immune thyroid disease "GD" (Okosieme et al., 2007; Elfadil et al., 2014). While (Nakamura et al., 2008), explained that the autoantibodies except TSH receptor antibodies (Abs), anti-thyroglobulin ( $\mathrm{Tg}$ ) Abs and anti-thyroid peroxidase (TPO) Abs were not significantly prevalent in patients with AITD despite a significantly high elevation of thyroid-related Ab. Other study with (Trbojević and Djurica, 2005), appeared TPO Abs are the hallmark of AITD and are present in $75 \%$ of patients with Graves' hyperthyroidism. The differences in antibody positivity may be due to racial and ethnic differences.

Human TPO was found to bind to both IgG and IgM from patients with autoimmune thyroid diseases. The binding of IgG to microsomes is inhibited by TPO (Balucan et al., 2013). TPO antibodies fix complement, and a complex of membrane and complement are formed, these complexes are present in autoimmune thyroid disease patients (Kandi and Rao, 2012). And also TPO induce cytotoxic of thyroid cells in vitro (Marcocci et al., 2005).

Anti-TPO antibody was founded in sera typically have high affinities for an immune-dominant region of the intact TPO molecule. Estimates of TPO-Abs prevalence depend on the sensitivity and specificity of the method employed (La'ulu et al., 2007). Approximately 70-80 \% of patients with Graves' disease have TPOAbs detected (Hutfless et al., 2011). However, the detection of TPO- Abs does not always precede the development of thyroid dysfunction. Further, some individuals with unequivocal TSH elevations, presumably resulting from autoimmune destructive disease of the thyroid, do not have TPO-Abs detected (Spencer et al., 2007). the absence of TPO-Ab in some patients with elevated TSH likely reflects the suboptimal sensitivity and/or specificity of current TPO-Abs tests or a non-autoimmune cause of thyroid failure (i.e. atrophic thyroiditis) (La'ulu et al., 2007

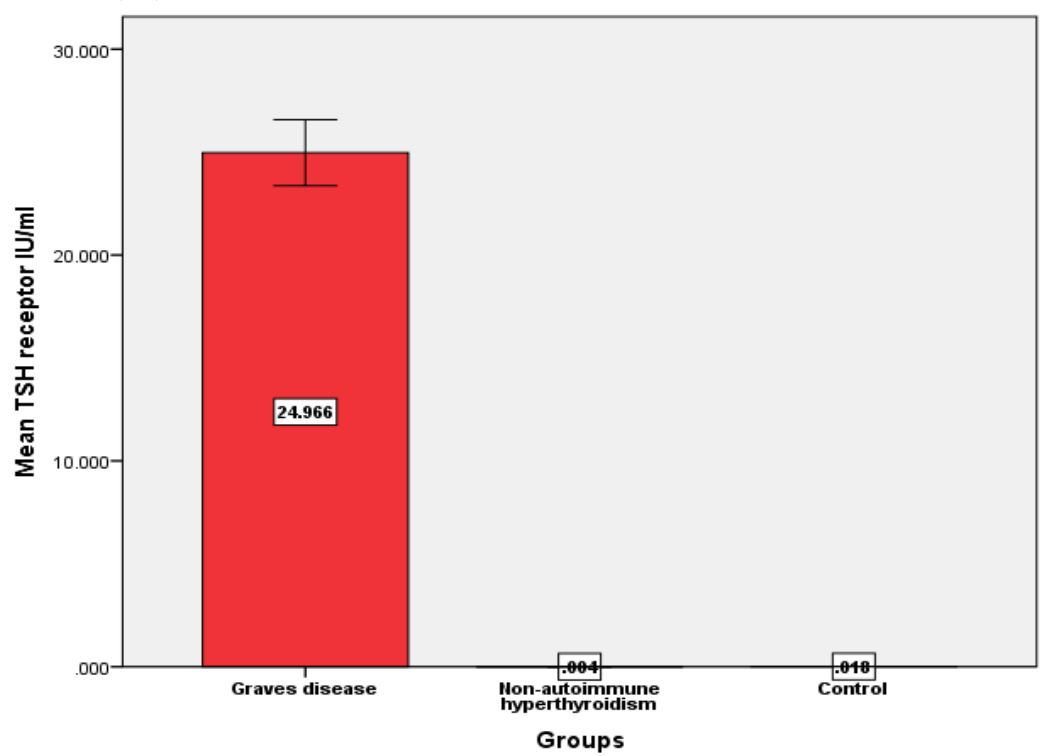

Figure(3-6) TSH receptor Ab. in different study groups. 


\section{Estimation of Serum Anti-TSHR Abs among Studied Groups:}

The anti-TSHR antibody that has been detected in sera of Graves' disease patients. Table (3-4) showed that a highly significant difference $(\mathrm{P}<0.001)$ between Graves' disease patients, non-autoimmune hyperthyroidism patients and healthy control group (24.965 $\pm 6.048,0.004 \pm 0.0019$ and $0.018 \pm 0.004$ respectively).

Thyroid auto antibodies (TSHR-Abs and TPO-Abs) are the markers of autoimmunity in autoimmune thyroid diseases (AL-Naqdy et al., 2003; Elmugadam et al., 2014). Graves' hyperthyroidism disease which is an autoimmune disease where the antibodies to the thyroid stimulating hormone receptor (TSHR) make the thyroid gland produce too much hormone (Kadhum and Hassan, 2014). TSHR autoantibodies play a direct role in the pathogenesis of AITD (Takasu and Matsushita, 2012). Therefore (TRAB) assay is helpful in diagnosis of Graves' disease when clinical features are not conclusive, and make as a golden diagnostic marker for Graves' disease (Elfadil et al., 2014).

In the current study the anti-TSHR antibody presented in a high number of GD patients with Anti-TSHR-Ab $\mathrm{n}=57(77.03 \%)$, out of total number patient's hyperthyroidism (74). This result agreed with other studied which conducted by Elfadil et al.,2014, who explained that a significant increased mean of TRAB in patients with Graves' as compared with hyperthyroidism patients and healthy control group (Elfadil et al., 2014). Amballi, reported that presence of TRAb in untreated Grave's disease was in $95 \%$ of patients were TRAb positive while $15 \%$ of patients diagnosed as nodular toxic goiter were TRAb positive (Amballi, 2007). A nother study, reported that $90 \%$ of patients were TRAb positive due to hyperthyroidism of Graves' disease that was distinguished clinically from the presence of a painless diffuse goiter (Pedersen, 2007). These finding and the presente study was agreed with recent local study in Iraq by Al-Gazally et al.2013, show stated that TRAb is a well-known marker of thyroid gland autoimmunity. Although not recommended as a first line test in the diagnosis of Graves' disease, the TRAb assay is more sensitive than a homogeneous thyroid scan and a palpation of a diffusely enlarged gland (89\% versus $78.1 \%$ and $74.8 \%$ ), clinical findings, the measurement of the anti TPO, and a radioiodine uptake of the thyroid cannot always give sufficient evidence to diagnose Graves' disease in some patients, so it can be important in the diagnosis of Graves' disease (Al-Gazally et al., 2014).

These table (3-4) shows significant difference between group 1 compared to group 2 and 3 in immunological parameter (TSH-receptor Ab. And Anti-TPO). TRAb is a well-known marker of thyroid gland autoimmunity. The antibodies are mainly produced by lymphocytic infiltrate in the thyroid gland and only to a small extent by regional lymph nodes or the bone marrow. Unlike antibodies against thyroglobulin (Tg), TPO antibodies are capable of inducing antibody-dependent cell-mediated cytotoxicity. Antibodies to TSH$\mathrm{R}$ mimic the function of TSH, and cause disease by binding to the TSH-R and stimulating (or inhibiting) thyroid cells. The TSHR, a member of the G protein-coupled receptor family with seven membranespanning segments. Patients with autoimmune thyroid disease may have both stimulating and blocking antibodies in their sera, the clinical picture being the result of the relative potency of each species (Trbojević and Djurica , 2005)

\subsection{Chemokines and graves disease.}

Table(3-5) Comparison between different groups of study regarding different marker of chemokines.

\begin{tabular}{|l|l|l|l|}
\hline Variables & Graves disease $(\mathbf{n}=\mathbf{5 7})$ & Non autoimmune $(\mathbf{n}=\mathbf{1 7})$ & Control $(\mathbf{n}=\mathbf{1 9})$ \\
\hline CCL10 Pg/ml & $182.12 \pm 41.76$ & $84.65 \pm 7.65^{*}$ & $75.98 \pm 20.48^{*}$ \\
\hline CCL20 Pg/ml & $12.06 \pm 2.097$ & $4.516 \pm 1.673^{*}$ & $4.907 \pm 4.206^{*}$ \\
\hline
\end{tabular}

*significant vsGraves disease............\#significant vs Non autoimmune. 
Table(3-6) Chemokines markers in different study groups among all age groups

\begin{tabular}{|c|c|c|c|c|c|}
\hline $\begin{array}{l}\text { Chemokines } \\
\text { marker }\end{array}$ & $\begin{array}{l}\text { Age } \\
\text { group }\end{array}$ & $\begin{array}{l}\text { Auto-immune graves } \\
\text { disease mean } \\
\mathrm{N}=57\end{array}$ & $\begin{array}{l}\text { Non-autoimmune } \\
\text { graves disease mean } \\
\mathrm{N}=17\end{array}$ & $\begin{array}{l}\text { Control } \\
\text { mean } \\
\mathrm{N}=19\end{array}$ & P.value \\
\hline \multirow{6}{*}{ CCL10 Pg/ml } & $20-25$ & 135.5143 & 64.9964 & 74.3501 & \multirow{6}{*}{0.616} \\
\hline & $26-30$ & 166.9318 & 73.0608 & 99.7703 & \\
\hline & $31-35$ & 146.7000 & 23.0986 & 94.4472 & \\
\hline & $36-40$ & 157.7455 & 13.7682 & 89.1129 & \\
\hline & $41-45$ & 151.6875 & 13.4672 & 102.9827 & \\
\hline & $>45$ & 164.9250 & 12.7820 & 107.6808 & \\
\hline \multirow{6}{*}{ CCL20 Pg/ml } & $20-25$ & 8.8386 & 5.7682 & 4.5117 & \multirow{6}{*}{0.679} \\
\hline & $26-30$ & 8.1132 & 4.9021 & 6.2370 & \\
\hline & $31-35$ & 9.5250 & 3.1523 & 6.9181 & \\
\hline & $36-40$ & 10.2509 & 4.8068 & 8.5729 & \\
\hline & $41-45$ & 9.4088 & 5.9490 & 7.3859 & \\
\hline & $>45$ & 9.1363 & 6.1615 & 6.6605 & \\
\hline
\end{tabular}

LDS show no significant difference between all age groups regarding all merker of chemokines. $(\mathrm{p}>0.05)$

\section{4-5-1.Age and Chemokines:}

Concentration of CCL10 and CCL20 associated negatively with age of studied group p>0.616,0.679 respctively not significant statistically between all age group regarding all marker of chemokines.

No statstical difference was found for these parameters of chemokines (CCL10 and CCL20) above in table (3-7) among all age groups.

Table(4-7) Chemokines markers among males and females in different study groups.

\begin{tabular}{|c|c|c|c|c|c|}
\hline \multirow{2}{*}{$\begin{array}{l}\text { Chemokines } \\
\text { markers }\end{array}$} & \multirow{2}{*}{ Sex } & \multirow{2}{*}{$\begin{array}{l}\text { Auto-immune graves } \\
\text { disease Mean } \\
n=57\end{array}$} & \multirow{2}{*}{$\begin{array}{l}\text { Non-autoimmune } \\
\text { graves disease Mean } \\
n=17\end{array}$} & \\
\hline & & & & $\begin{array}{l}\text { Control } \\
\text { Mean } n=19\end{array}$ & P.value \\
\hline \multirow{2}{*}{ CCL10 Pg/ml } & $\mathrm{F}$ & 149.7115 & 86.8839 & 91.18 & \multirow{2}{*}{0.009} \\
\hline & $\mathrm{M}$ & 105.7867 & 91.4917 & 89.62 & \\
\hline \multirow{2}{*}{ CCL20 Pg/ml } & $\mathrm{F}$ & 9.5640 & 5.4627 & 6.1401 & \multirow{2}{*}{0.066} \\
\hline & $\mathrm{M}$ & 7.4573 & 6.9230 & 7.531 & \\
\hline
\end{tabular}

Chemokines and gender

No correlation was found between gender and chemokines marker (CCL10 and CCL20) these result fits of (Pham et,al 2012)who found that no different between males and females in level of CCL10 and CCL20 in serum hyperthyrodim.

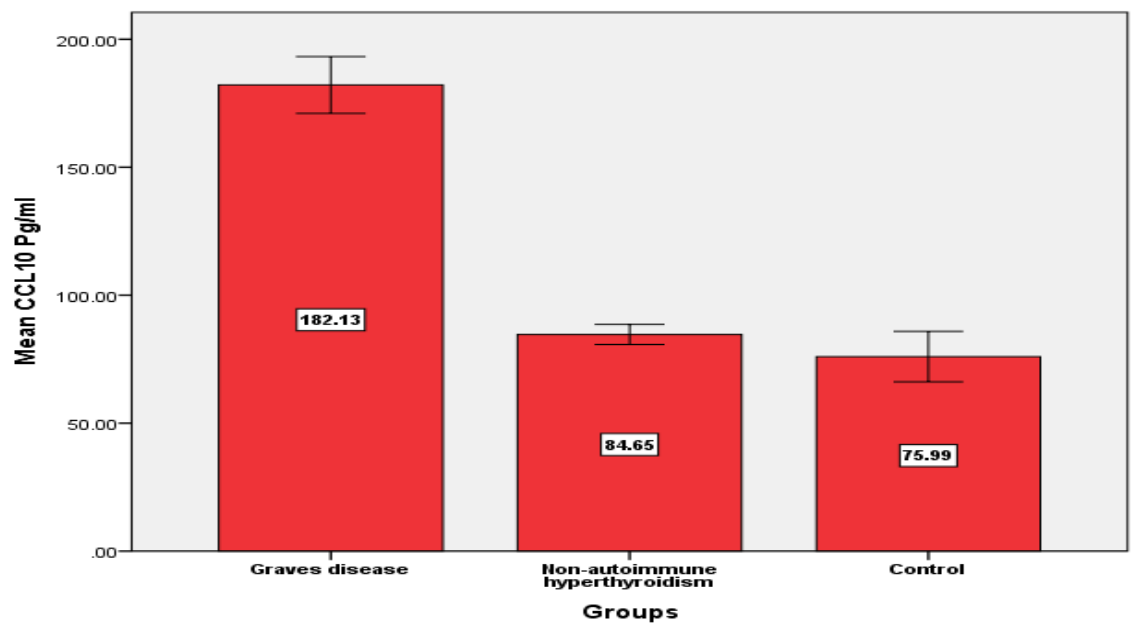

Figure(3-7) Mean CCL10 level in different study groups. 
The CCL10 that has been detected in sera of Graves' disease patients. figure (3-7), showed that a highly significant difference $(\mathrm{P}<0.001)$ between Graves' disease patients, non-autoimmune hyperthyroidism patients and healthy control group (182.13 $\pm 41.76,84.65 \pm 7.65$ and $75.98 \pm 20.48$ respectively). While, Table (3-7) was presented a high number of patients that have auto antibodies CCL10 in sera $(n=55)$ (96.4\%) out of a total number (57) of autoimmune Graves' hyperthyroidism patients, depended on Cut-off value.(75.98+-4.2) $\mathrm{pg} / \mathrm{ml}$. ......... Negative (Healthy patients) $(182.12+-41.76) \mathrm{pg} / \mathrm{ml}$.in graves disease auto immune disease.

Our result is correlated with pharm et al(2012) study who found that autoimmune Graves diseases patients had an increased level of circulating CCL10 when compared with non-auto-immune graves disease and control.

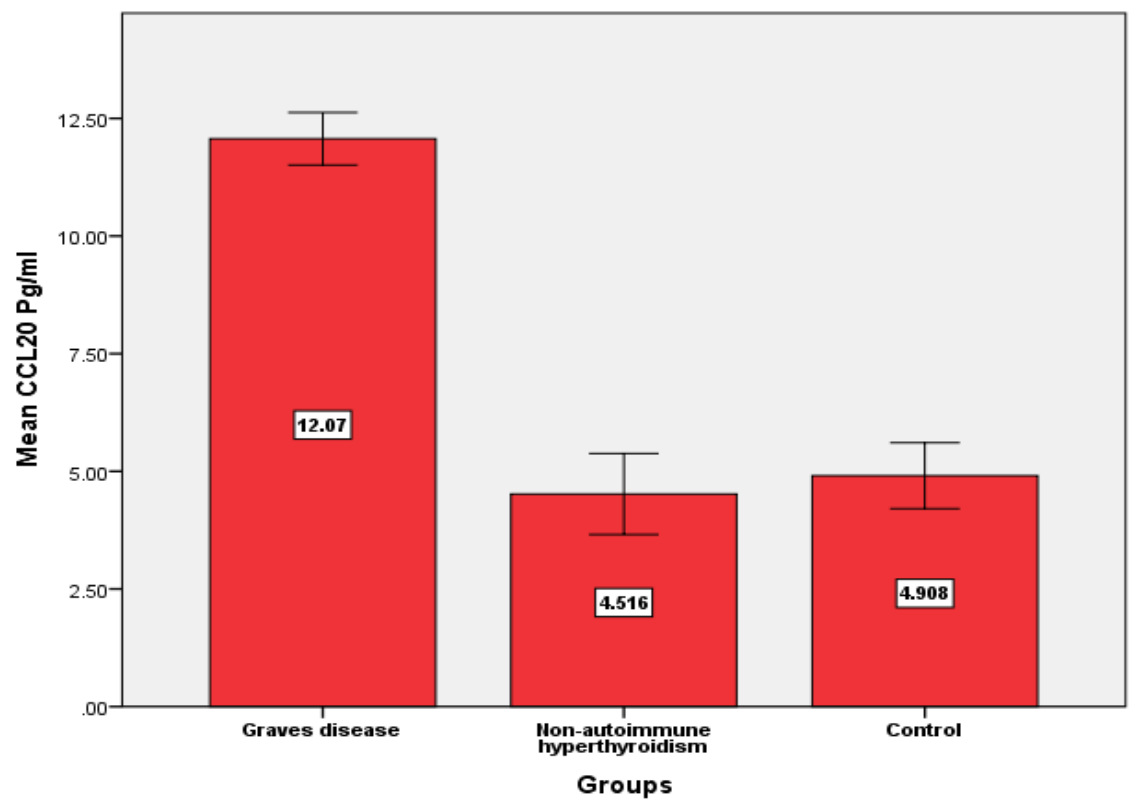

Figure(3-8) Mean CCL20 level in different study groups.

The CCL20 antibody that has been detected in sera of Graves' disease patients. Figure (3-8), showed that a highly significant difference $(\mathrm{P}<0.001)$ between Graves' disease patients, non-autoimmune hyperthyroidism patients and healthy control group $(12.07 \pm 2.097,4.516 \pm 1.673$ and $4.908 \pm 4.206$ respectively). While, Table (3-5) was presented a highly number of patients that have aCCL 10 in sera $(n=56)(98.2 \%)$ out of a total number (57) of autoimmune Graves' hyperthyroidism patients.

Table(3-5) showed significant difference between group 1 compared to group 2 and 3 in chemokines parameters concentration under study. The result showed significantly higher values of CCL10 and CCL20 in graves disease patients compared to non -autoimmune hyperthyroidism and graves disease $\mathrm{P}=0.009$ and 0.066 respectly . The CCL10 increased in graves disease pateints mean( 182.12+-41.76)pg/ml. compared with non-autoimmune hyperthyroidism and control(84.65+-7.65,75.98+-20.48)pg/ml respectly. and CCL20 in graves disease patients (12.06+-2.097) $\mathrm{pg} / \mathrm{ml}$. compared with non-autoimmune hyperthyroidism and control(4.516+-1.673,4.907+-4.206)pg/ml. respectly.

Our result is in line of (pham et al 2012 and sayinalp et,al 1996)study who found that Graves disease had an increased level of circulating CCL10,CCL20 when compared with non-autoimmune hyperthyroidism and control group, the result significant and differ the level of CCL10,CCl20 in different groups studies in other study by(Itoh et,al1998) these results agree with our results. 
Table(3-8)Association between different markers and graves disease.

\begin{tabular}{|l|l|l|l|l|l|l|}
\hline $\begin{array}{l}\text { Immune } \\
\text { markers }\end{array}$ & $\begin{array}{l}\text { Graves } \\
(\mathbf{n = 5 7 )}\end{array}$ & $\begin{array}{l}\text { Mean } \\
\text { Concentration }\end{array}$ & control(n=19) & $\begin{array}{l}\text { Mean } \\
\text { Concentration }\end{array}$ & P value & OR(95\% CI) \\
\hline CCL10 & $55(96.4 \%)$ & $182.12+-41.8$ & $0(0 \%)$ & 0 & $<0.001$ & inf.(55.5-inf.) \\
\hline CCL20 & $56(98.2 \%)$ & $12.1+-201$ & $0(0 \%)$ & 0 & $<0.001$ & inf.(77.6-inf.) \\
\hline
\end{tabular}

Table(3-9) Association between different markers and non autoimmune hyperthyroidism.

\begin{tabular}{|l|l|l|l|l|l|l|}
\hline $\begin{array}{l}\text { Immune } \\
\text { markers }\end{array}$ & $\begin{array}{l}\text { Non autoimmune } \\
(\mathbf{n = 1 7 )}\end{array}$ & $\begin{array}{l}\text { Mean } \\
\text { Concentration }\end{array}$ & control(n=19) & $\begin{array}{l}\text { Mean } \\
\text { concentration }\end{array}$ & P value & OR(95\%CI) \\
\hline CCL20 & $2(11.7 \%)$ & 5.097 & $0(0 \%)$ & 0 & 0.124 & inf.(0.507-inf. $)$ \\
\hline
\end{tabular}

In table(3-8),(3-9) there was a marked increase chemokines in patients with Graves' disease as compared to non auto-immune hyperthyroidism and normal control individuals, and this can be attributed to generalized B- cell activation (Sayinalp et al., 1996). This result was in agreement with Jafarzadeh et al., (2010), who reported that a higher levels Chemokines patients with hyperthyroidism. Also Al-Humaidi, (2000), who stated that there were significantly higher level of chemokines in GD patients than in the control group $\mathrm{P}<0.001)$. In other study, by Itohet al., (1998), they reported the same as in the present study, In a study was done by Sayinalp et al, they presented results which compatible with our results, they stated that a serum chemokines detect ability ratio was higher in patients with GD than in the other non-autoimmune hyperthyroidism group $(\mathrm{P}<0.001)$; An underlying state of autoimmune thyroid disease may be a permissive factor for this phenomenon (Sayinalp et al., 1996). It is believed that B cell activation is up-regulated in patients with Graves' disease because of detectable anti-thyroid auto-antibodies, the increased production of $\mathrm{B}$ cell growth factors by peripheral and intrathyroidal $\mathrm{T}$ lymphocytes, and the increased number of peripheral blood chomkines present.

The Th2 dominates in Graves' thyroid-infiltrating cells was demonstrated by an increased ratio of CCL10 to CCL20 production. IL-12 is a key regulatory chemokine produced mostly by APC (Adorini et al., 1996) and (Adorini et al., 1997).

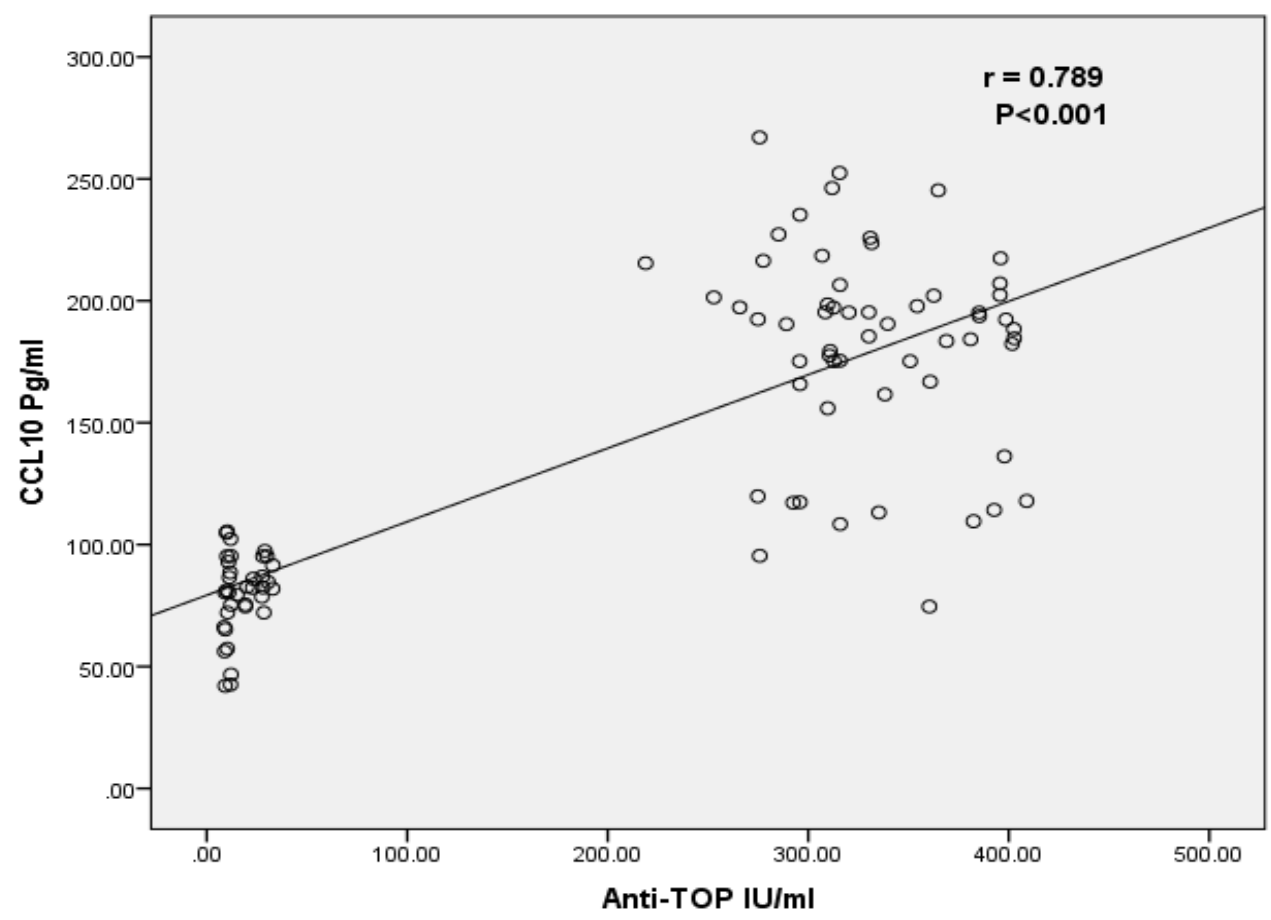

Figure (3-9) Correlation between CCL10 and anti-TOP.

There is strong significant positive correlation between anti-TOP and CCL10 . $\mathrm{R}=0.789 \ldots . \mathrm{P}<0.001$ 


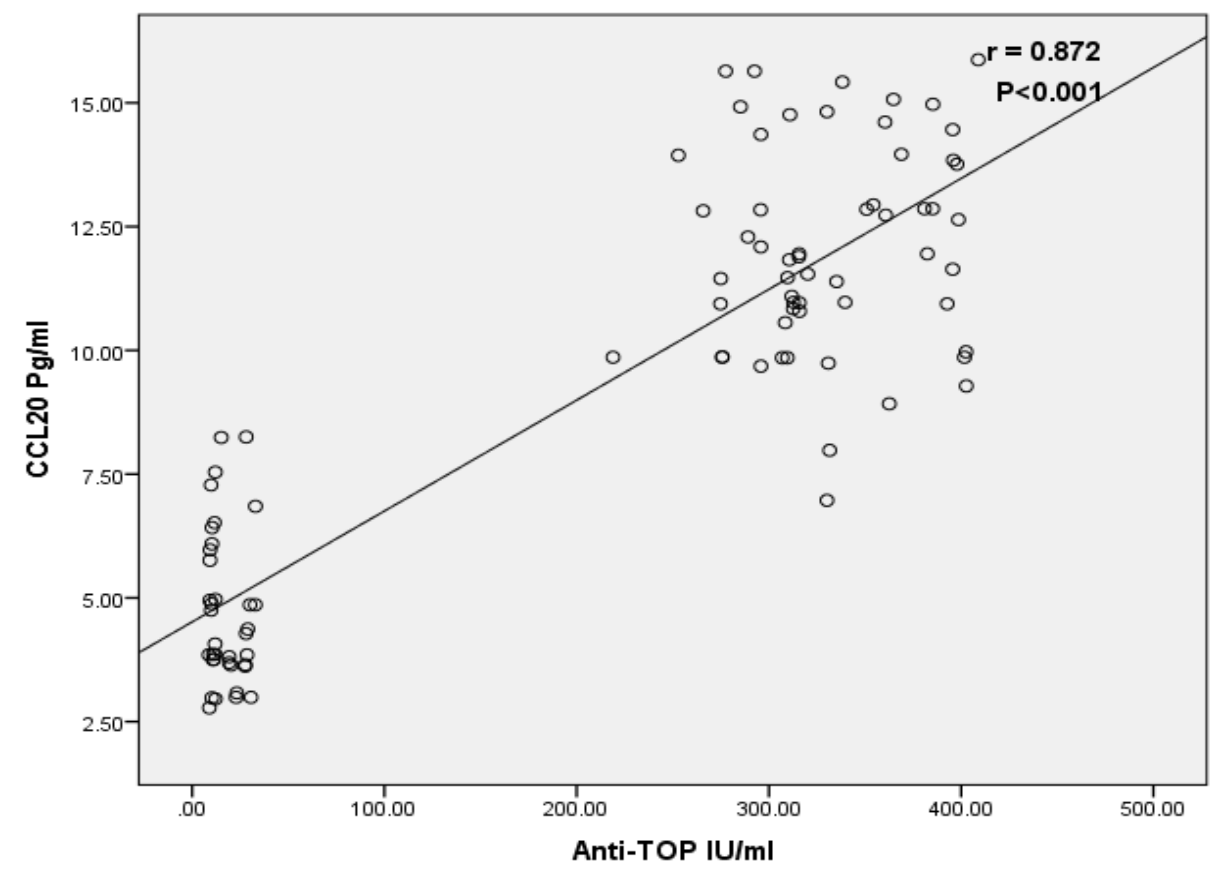

Figure(3-10) Correlation between CCL20 and anti-TPO.

In figure (3-10)there is very strong significant positive correlation between CCL20 and anti-TPO.

$\mathrm{R}=0.82$

$\mathrm{P}<0.001$

In some patients, the simultaneous production of antibodies that block the thyrotropin receptor reduces the stimulatory action of thyroid-stimulating antibodies. For these reasons there is no direct correlation between serum concentrations of thyroid-stimulating antibodies and serum thyroid hormone concentrations in patients with Graves'.

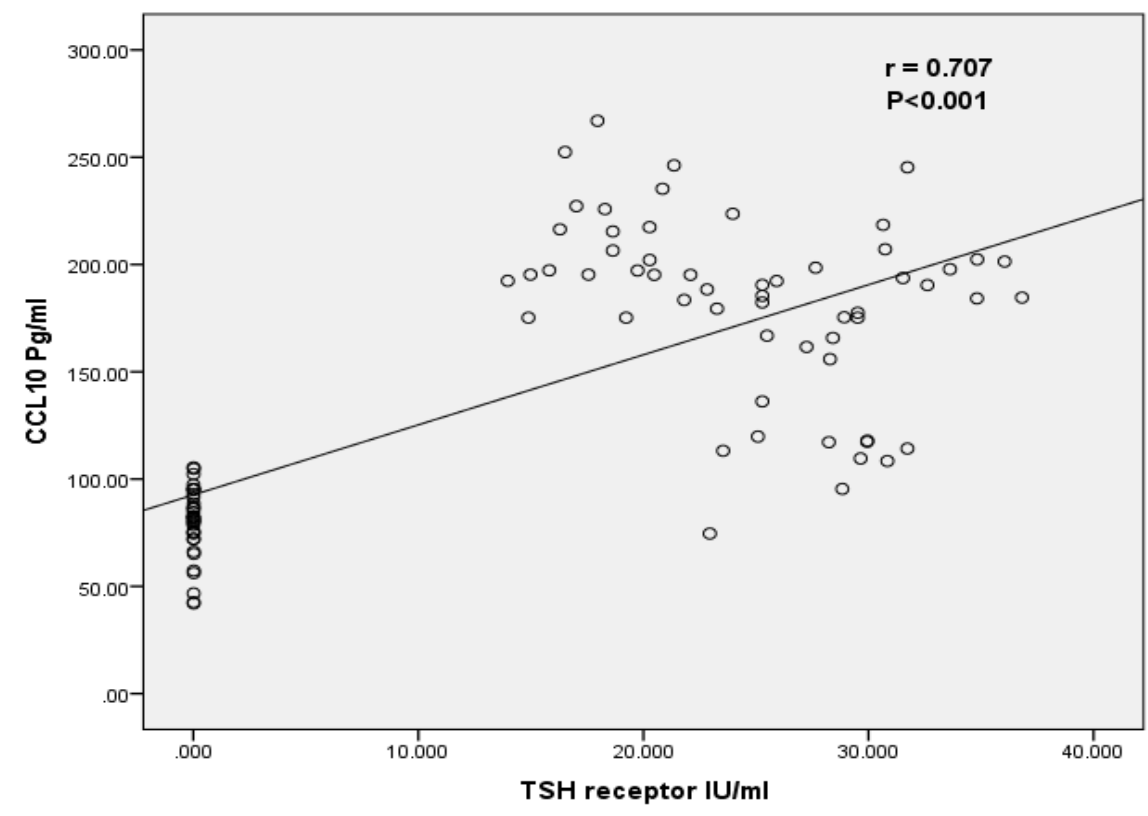

Figure(3-11) Correlation between CCL10 Anti- TSH receptor Ab.

There is significant strong positive correlation between CCL10 and Anti- TSH receptor Ab. as shown in figure( $3-11)$ $\mathrm{R}=0.707$ $\mathrm{P}<0.001$ 


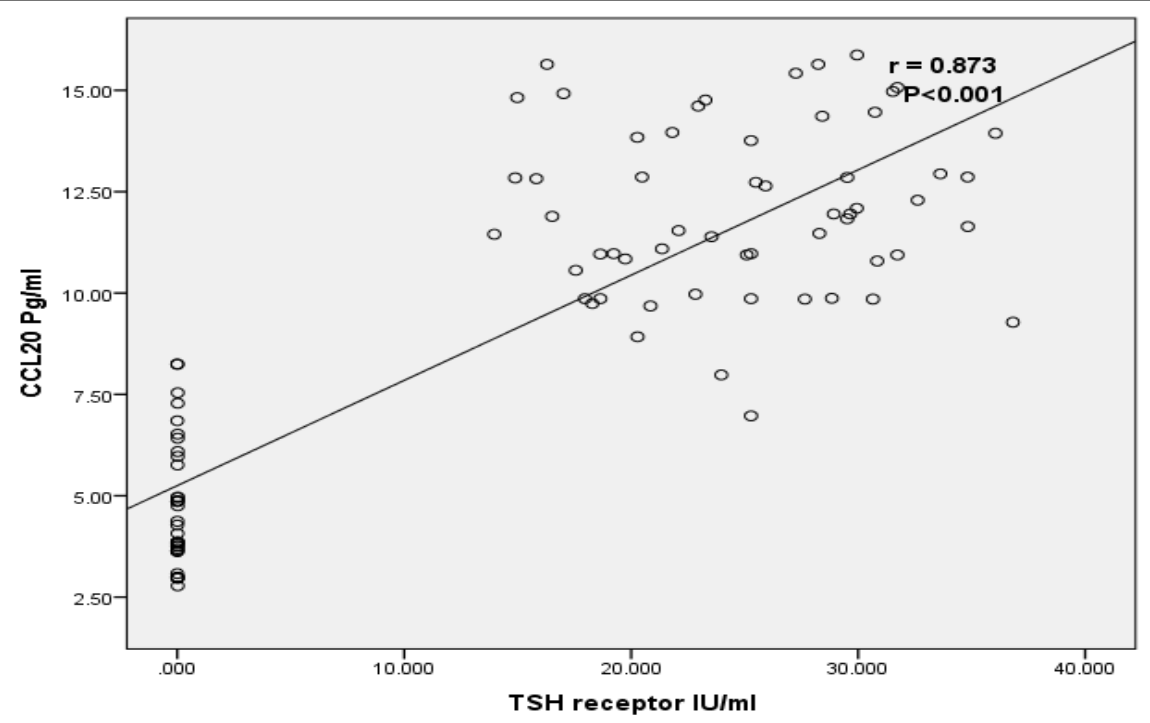

Figure (3-12) Correlation between CCL20 and TSH receptor Ab.

There is significant very strong positive correlation between CCL20 and TSH receptor.

$\mathrm{R}=0.783$

$\mathrm{P}<0.001$

In this study, results revealed the highly significant positive correlation between Anti-TSHR antibody and chemokines CCL10 correlation wih TSHR Ab. $(r=0.707, p<0.001)$ and CCL20 ( $r=0.893, p<0.001)$ Our observation was agreed with Khin et al., (2007) who showed that the correlation between TRAB and degree of thyrotoxicosis (T4 at diagnosis), $\mathrm{r}$ value $0.52, \mathrm{P}<0.01$. Chen et al., (2003) was presented TSHR autoantibodies detected in more than $90 \%$ of untreated Graves's patients, and TSHR Abs titer correlate closely with the severity of hyperthyroidism.

The relationship between the TSH receptor antibodies and the excess production of thyroid hormones suggests the activation of B cells and dominance of humeral immune responses in patients with Graves' disease (Itoh et al., 2002). In Graves' disease, autoantibodies bind to the receptor and mimic TSH action and stimulate thyroid cells. This leads to hyperthyroidism and abnormal overproduction of thyroid hormone (Chistiakov, 2003; Brand et al., 2009).

Table(3-10) Validity of CCL10 in diagnosing Graves disease from nonautoimmune hyperthyroidism

\begin{tabular}{|c|c|c|c|c|}
\hline \multirow{2}{*}{} & \multicolumn{2}{|c|}{ Groups } & \multirow{2}{*}{ Total } \\
\cline { 3 - 5 } & \multirow{3}{*}{ High } & Graves disease & Non-autoimmune hyperthyroidism & \\
\cline { 3 - 5 } CCL10 & 55 & 0 & 55 \\
\cline { 3 - 5 } & \multirow{3}{*}{ Normal } & $100.0 \%$ & $0.0 \%$ & $100.0 \%$ \\
\cline { 3 - 5 } & & 2 & 17 & 19 \\
\cline { 3 - 5 } & \multirow{2}{*}{ Total } & 57 & $89.5 \%$ & $100.0 \%$ \\
\cline { 3 - 5 } & $77.0 \%$ & 17 & 74 \\
\hline \multicolumn{2}{|c|}{} & & $23.0 \%$ & $100.0 \%$ \\
\hline
\end{tabular}

$\begin{array}{llll}\text { Sensitivity }=96.5 \% & \text { Specificity }=100 \% & \text { PPV }=100 \% & \text { NPV }=89.4 \%\end{array}$

Table (3-11) Validity of CCL20 in diagnosing Graves disease from non autoimmune hyperthyroidism

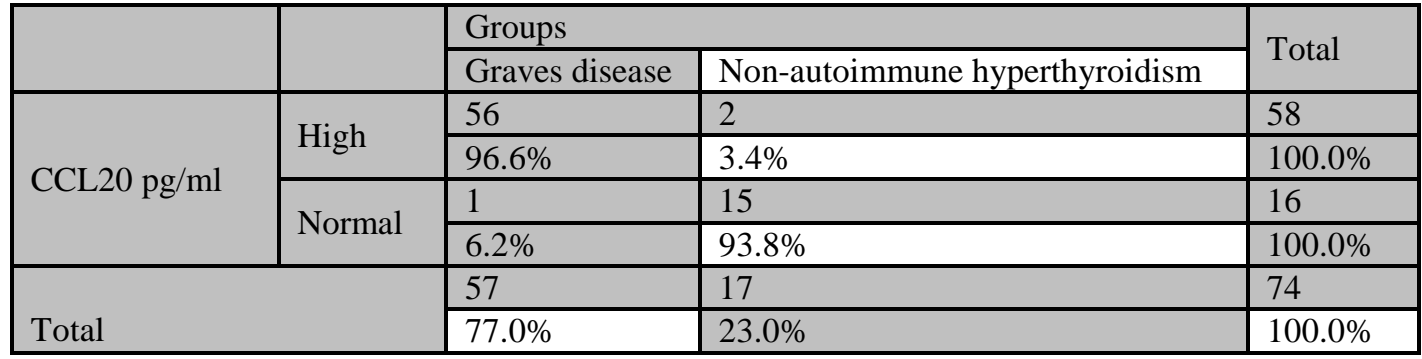

$\begin{array}{llll}\text { Sensitivity }=98.2 \% & \text { Specificity }=88.2 \% & \mathrm{PPV}=96.5 \% & \mathrm{NPV}=93.7 \% \mathrm{~b}\end{array}$ 
From table (3-10),(3-11),,it was found that this assay has high sensitivity and excellent specificity for detection of CCL10 $=100 \%$ and CCL20 $=88.2$ these validity used in diagnosis Graves diseases from nonautoimmune hyperthyroidism.

The sensitivity of this assay, or Lower Limit of Detection (LLD) was defined as lowest concentration that could be differentiated from zero.(La ulu et al., 2007).

It was determined by adding two stander devations-the mean optical density value of twenty zero standared replicates and calculation of corresponding concentration.

The sensitivity of CCL20 $=98.2 \%$. The high validity in diagnosis Graves disease from non-autoimmune hyperthyroidism by estimation of chemokines depending on sensitivity and specificity of the method employed (La ulu et al., 2007).

\section{Conclusions}

1) TSH-receptor Abs is helpful in diagnosis of Graves' disease when clinical features are not conclusive in primery diagnosis.

2) Autoimmune thyroid disorders are examples of common diseases in which chemokines play an important role

3) High serum level CCL20 of might easly enhance Graves disease and decreased in non immune hyperthyroidism TRAb-Negative graves disease. The result demonstrated that $\mathrm{CCl} 20$ might serve as abiomarker for Graves disease

4) The result of the present study confirmed that CCL10 serum level are increased in patient who are newly diagnosed as Graves disease and demonstrate astrong association with hyperthyroid phase of the disease and decrease of CCL10 in non-immune graves disease patient and control.

\section{Recommendations}

1- Thyroid function tests (TSH, T4, T3) were recommended for patients with Graves disease as aroutine test.

2- Further studies should be conducted on chemokines to explain their role in pathogensis of Graves disease.

3- Larger sample size should be tried to explain the distribution of Graves disease inNajafprovine.

4- Other types of chemokines should be investigated to obtain a solid evidence of their association with Graves diseases.

\section{Reference}

1. Adorini L., Gregori S., Magram J. and Trembleau S., (1996). The role of IL-12 in the pathogenesis of Th1 cell-mediated autoimmune diseases. Ann. NY. Acad. Sci. 795: 208-215.

2. Adorini L., Gue'ry J.C., Ria F. and Galbiati F., (1997). B cells present antigen to CD4+ T cells, but fail to produce IL-12: Selective APC for Th2 cell development? Ann. NY. Acad. Sci.; 815: 401-411.

3. Ajjan R.A., Kemp E.H., Waterman E.A., Watson P.F., Endo T., Onaya T. and Weetman A.P., (2000). Detection of binding and blocking autoantibodies to the human sodium-iodide symporter in patients with autoimmune thyroid disease. J. Clin. Endocrinol. Metab.; 85:2020-2027.

4. Akbar D.H., Mushtaq M.M., Al-Sheik A.A., (2000). Etiology and outcome of thyrotoxicosis at a university hospital. Saudi Med. J.; 21(4): 352-4.

5. AL-Bustany D.A., (2011). Clinical study of cases with hyperthyroidism in Erbil Governorate, Kurdistan Region-Iraq. Zanco J. Med. Sci.; 15:1. 
6. AL-Fatlawi R.B. (2014). The association between HLA-DQ alleles and the autoimmune thyroid diseases (AITDs) among Iraqi patients. MSc thesis, Medical Microbiology/Clinical immunology; University of $\mathrm{Kufa} / \mathrm{Iraq}$.

7. AL-Gazally M.E., Al-shalah M.A. and Muttaleb S.A., (2013). The Role of Thyrotropin Hormone Receptor Antibody (TRAb) in Distinguishing between Autoimmune and non-Autoimmune Disease. Med. J. of Babylon; 10(1):153-161.

8. AL-Humaidi M.A, (2000). Serum Cytokines Levels in Graves ' disease. Saudi med. J; 21 (7): 639-44

9. AL-Naqdy A., Kutty I., AL-Harthi S., AL-BuloshiM., AL-Maskari M., (2003). Anti-thyroid microsomal antibodies in thyroid disorders. Bahrain Med. Bulletin; 25:3.

10. Al-Rubaye I.A.H., (2006). Immunogenetic study and autoantibody status in type 1 Diabetic patient and their siblings. MSc Thesis; Ministry of Higher Education and Scientific Research; University of Baghdad; College of Science: P: 2.

11. Amballi A.A., (2007). Thyrotocosis. Middle-East J. of sci.; 2(3-4): 98-103.

12. Ando T. and Davies T.F., (2013). Postpartum autoimmune thyroid disease: the potential role of fetal microchimerism. J. of Clin. Endocrinol. And Metab.; 88(7): 2965-2971.

13. Baker J.R., (2001). Guest editorial. Thyroid; 11: 245-247.

14. Davies T.F., (2007). Really significant genes for autoimmune thyroid disease do not exist--so how can we predict disease? Thyroid; 17: 1027-9.

15. Davies T.F., Yin X., and Latif R., (2010). The Genetics of the Thyroid Stimulating Hormone Receptor: History and Relevance. Inc. Thyroid; 20:727.

16. Davies TF , Roti E, Braverman LE, DeGroot U. IThyroid controversy--stimulating antibodies. $J$ ClinEndocrinolMetab. 1998 Nov;83

17. Del Prete G., (1998). The concept of type-1 and type-2 helper T cells and their cytokines in humans. Intern. Rev. Immunol.; 16: 427-455.

18. Delespesse G., Sarfati M., Wu C.Y., Fournier S. and Letellier M., (1992). The low affinity receptor for IgE. Immunol. Rev.; 125:77-97.

19. Dorner T. and Lipsky P.E., (2006). Signalling pathways in B cells: implications for autoimmunity. Curr. Top. Microbiol. Immunol.; 305: 213-240.

20. Douglas R.S., Naik V., Hwang C.J., Afifiyan N.F., Gianoukakis A.G., Sand D., Kamat S., and Smith T.J., (2008). B cells from patients with graves disease.

21. Duntas L.H., (2008). Environmental factors and autoimmune thyroiditis. Nat. Clin. Pract. Endocrinol. Metab.; 4: 454-460.

22. Elfadil G.A., Eltahir I.E.M and Elmugadam A.A., (2014). Anti-TRA-Ab, Anti-TPO-Ab, and FT3 as a Biochemical Panel for Differential Diagnosis of Graves' Disease from Hyperthyroidism. Ind. J. of App. Research; 4(5): 408-410.

23. Eschler D.C., Hasham A. and Tomer Y., (2011). Cutting edge: the etiology of autoimmune thyroid disease. Clin. Rev. allergy Immunol.; 41: 190-197.

24. Fairweather D., (2007). Autoimmune Disease Mechanisms. J. Hopkins University, Bloomberg School of Public Health, Baltimore, Maryland, USA.

25. Frisancho-Kiss S. and Rose N.R.F.D., (2008). Sex differences in autoimmune disease from a pathological perspective. J. Pathol.; 173(3): 600-9.

26. Garber J.R., Cobin R.H., Gharib H., Hennessey J.V., Klein I., Mechanick J.I., Pessah-Pollack R., Singer P.A. and Woeber K.A., (2012). Clinical Practice Guidelines for Hypothyroidism in Adults.

27. Glinoer D., (2004). The regulation of thyroid function during normal pregnancy: Importance of the iodine nutrition status. Best Practice and Research: Clin. Endocrinol. and Metab.; 18(2): 133-152. 
28. Hadj-Kacem H., Rebuffat S., Mnif-F eki M., Belguith-Maalej S., Ayadi H., and eraldi-Roux S.P, (2009). Autoimmune thyroid diseases: genetic susceptibility of thyroid-specific genes and thyroid autoantigens contributions. Inter. J. of Immunogen.; 36(2): 85-96.

29. Hammerstad S.S. and Tomer Y., (2015). Graves' disease. A Comprehensive Guide for Clinicians; Chapter 3: 21-37.

30. Hampe C.S., (2012). B Cells in Autoimmune Diseases. Review Article; Scientifica.; Vol. 2012: 1-18.

31. Hasham A. and Tomer Y., (2012). Genetic and epigenetic mechanisms in thyroid autoimmunity. Immunol. Res.; 54(1-3): 204-213.

32. Hegazi M.O. and Ahmed S., (2012). Atypical Clinical Manifestations of Graves' disease: An Analysis in Depth. J.of Thyroid Research; Vol. 2012: 1-8.

33. Hobby P., Gardas A., Radomski R., McGregor A.M., Banga J.P. and Sutton B.J., (2000). Identification of an immunodominant region recognized by human autoantibodies in a threedimensional model of thyroid peroxidase. Endocrinol.; 141: 2018-2026.

34. Hodkinson C.F., Simpson E.E.A., Beattie J.H., O’Conor J.M., Campbell D.J., Strain J.J. and Wallace J.M., (2009). Preliminary evidence of immune function modulation by thyroid hormones in healthy men and women aged 55-70 years. J. Endocrinol.; 202: 55-63.

35. Hollowell J.G., Staehling N.W., Flanders W.D., et al., (2002). Serum TSH, T4, and thyroid antibodies in the United States population (1988 to 1994): National Health and Nutrition Examination Survey (NHANES III). J. Clin. Endocrinol. Metab.; 87: 489-99.

36. Holmes N. (2001). Immunology part IB home page. Department of Pathology, University of Cambridge.

37. Hopton M.R. and Harrap J.J., (1986). Immunoradiometric assay of thyrotropin as a first line thyroid function test in the routine laboratory. Cli. Chemis.; 32:691.

38. Hutfless S., Matos P., Talor M.V., Caturegli P. and Rose N.R., (2011). Significance of prediagnostic thyroid antibodies in women with autoimmune thyroid disease. J. Clin. Endocrinol. Metab.; 96: E1466-1471.

39. Iddah M. A., and Macharia B. N., (2013). Autoimmune Thyroid Disorders. ISRN Endocrinol.; Vol. 2013: 1-9.

40. Iglesias P., Devora O., Garcia J., Tajada P., Garcia A. C. and Diez J.J., (2009). Sever hyperthyroidism: etiology, clinical features and treatment outcome. J. Clin. Endocrinol; 72(4): 551-7

41. Inaba H., Moise L., Martin W., De Groot A.S., Desrosiers J., Tassone R., Buchman G., Akamizu T. and De Groot L.J., (2013). Epitope recognition in HLA-DR3 transgenic mice immunized to TSH-R protein or peptides. Endocrinol.; 154(6): 2234-43.

42. Itoh M., Uchimura K., Yamamoto K., Makino M., Imamura S., Kobayashi T., Fujiwara K., Kato T., Hayakawa N., Sawai Y., Nagasaka A., Iwase K., Nomura T., Hagino Y., (2002). Distinctive response of thyroid- infiltrating mononuclear cells to B cell activation through CD40 and interleukin4 in Graves' patients. cytokine; 19(3): 107-114.

43. Iwama S., Ikezaki A., Kikuoka N. and et al., (2005). Association of HLA-DR, -DQ genotype and CTLA-4 gene polymorphism with Graves' disease in Japanese children. Horm. Res.; 63: 55-60.

44. Iwama S., Ikezaki A., Kikuoka N. and et al., (2005). Association of HLA-DR, -DQ genotype and CTLA-4 gene polymorphism with Graves' disease in Japanese children. Horm. Res.; 63: 55-60.

45. Jacobson E.M. and Tomer Y, (2007). The genetic basis of thyroid autoimmunity. Thyroid; 17:949-61

46. Jacobson E.M., Huber A. and Tomer Y. (2008). The HLA gene complex in thyroid autoimmunity: from epidemiology to etiology. J. Autoimmun.; 30: 58-62. 
47. Jacobson E.M., Yang H., Menconi F., Wang R., Osman R., Skrabanek L. and et al., (2009). Employing a recombinant HLA-DR3 expression system to dissect MHC II-thyroglobulin peptide dynamism: a genetic, biochemical, and reverse immunological perspective. J. Biol. Chem.; 284: 34231-34243.

48. Jafarzadeh A., Poorgholami M., Izadi N., Nemati M., and Rezayati M., (2010). Immunological and hematological changes in patients with hyperthyroidism or hypothyroidism. Clin. Invest. Med.; 33 (5): E271-E279.

49. Jaume J.C., Guo J., Pauls D.L., Zakarija M., McKenzie J.M., Egeland J.A., Burek C.L., Rose N.R., Hoffman W.H., Rapoport B. and McLachlan S.M., (1999). Evidence for genetic transmission of TSHR GENETICS

50. Jiang L., Wang G.L., Dong J.J., Shu Q., Guo C.H., Zhang X.L., Chen F.Q., (1999). The relationship between CTLA-4 gene polymorphism and Graves' disease in Chinese. Chin. J. of Endocrinol. and Metab.; 15(5): 215-216.

51. Jobim M., Chagastelles P., Salim P.H., Portela P., Wilson T.J., Curti A.G., Jobim M.R., Joo D.A., Nardi N.B., Tschiedel B., Jobim L.F., Roesler R. and Schwartsmann G., (2010). Association of killer cell immunoglobulin-like receptors and human leukocyte antigen-C genotypes in South Brazilian with type 1 diabetes. Hum. Immunol.; 71: 799-803.

52. Jonklaas J. and Talbert R.L., (2011). Thyroid Disorders. In : DiPiro J.T., Talbert R.L., Yee G.C., Matzke G.R., Wells B.G., Posey L.M., [eds]. Pharmacotherapy: A Pathophysiological Approach. 8th ed. New York, NY: McGraw-Hill.

53. Jurecka- Lubieniecka B., Ploski R., Kula D., Krol A., Bednarczuk T., Kolosza Z., Tukiendorf A., Szpak-Ulczok S., Stanjek-Cichoracka A., Polanska J and Barbara Jarzab B., (2013). Association between Age at Diagnosis of Graves' disease and Variants in Genes Involved in Immune Response. Plos One; 8(3): 1-6.

54. Kadhum E.W. and Hassan A.J., (2014). Study of some aspects of autoimmune response for patients of thyroiditis. J. phar. and Biol. sci. (IOSR-JPBS); 9(6), Ver II: 1-4.

55. Kamath C., Adlan M.A., and Premawardhana L.D., (2012). The Role of Thyrotrophin Receptor Antibody Assays in Graves' Disease. J. of Thyroid Res.; Vol. 2012: 8 pages.

56. Kandi S., Rao P., (2012). Anti-thyroid peroxidase antibodies: Its effect on thyroid gland and breast tissue. Editorial Commentary; 5(1): 1-2.

57. Kasper D. and et al., (2012). Hyperthyroidism (Graves' disease). Harrison's practice.

58. Kavvoura F.K., Akamizu T., Awata T. and et al., (2007). Cytotoxic T- lymphocyte associated antigen 4 gene polymorphisms and autoimmune thyroid disease: a meta-analysis. J. Clin. Endocrinol. Metab.; 92: 3162-70.

59. Kavvoura F.K., Akamizu T., Awata T. and et al., (2007). Cytotoxic T- lymphocyte associated antigen 4 gene polymorphisms and autoimmune thyroid disease: a meta-analysis. J. Clin. Endocrinol. Metab.; 92: 3162-70.

60. Khalilzadeh O., MojaziAmiri H., Tahvildari M. and et al., (2009). Pretibial myxedema is associated with polymorphism in exon 1 of CTLA-4 gene in patients with Graves' ophthalmopathy. Arch. Dermatol. Res.; 301: 719-723.

61. Khin S.M., Gayathridevisa S.N., Ian M.F., Mark G., Diana W., Khris C. and Helen S., (2007). Use of Anti-Thyroid Hormone Receptor antibody (TRAB) in Graves' disease. Endocrine. Abstracts; 13: 81.

62. Kimkong I., Nakkuntod J., Sae-Ngow S., Snabboon T., Avihingsanon Y. and Hirankarn N., (2011). Association between CTLA-4 polymorphisms and the susceptibility to systemic lupus erythematosus and Graves' disease in Thai population. Asian Pac. J. Allergy Immunol.; 29: 229-235. 
63. Kimura H., Kato Y., Shimizu S., Takano K. and Sato K., (2009). Association of polymorphism at position 49 in exon 1 of the cytotoxic T-lymphocyte-associated factor 4 gene with Graves' disease refractory to medical treatment, but not with amiodarone-associated thyroid dysfunction. Thyroid; 19: 975-981.

64. Kinjo Y., TakasuN.,Komiya I. and et al., (2002). Remission of Graves' hyperthyroidism and A/G polymorphysim at position 49 in exon 1 of cytotoxic T lymphocyte-associated molecule-4 gene. $J$. Clin. Endocrinol. Metab.; 87: 2593-6.

65. Lantz, M. and et al., (2009). Immigration and the incidence of Graves' thyrotoxicosis, thyrotoxicmultinodular goiter and solitary toxic adenoma. Eur. J. Endocrinol.; 160: 201-6.

66. Lantz, M. and et al., (2009). Immigration and the incidence of Graves' thyrotoxicosis, thyrotoxicmultinodular goiter and solitary toxic adenoma. Eur. J Endocrinol.; 160: 201-6.

67. Latrofa F., Ricci D., Grasso L., Vitti P., Masserini L., Basolo F., Ugolini C., Mascia G., Lucacchini A. and Pinchera A., (2008). Characterization of thyroglobulin epitopes in patients with autoimmune and non-autoimmune thyroid disease using recombinant human monoclonal thyroglobulin autoantibodies. J. Clin. Endocrinol. Metab.; 93: 591-6.

68. La'ulu S.L., Slev P.R. and Roberts W.L., (2007). Performance characteristics of 5 automated thyroglobulin autoantibody and thyroid peroxidase autoantibody assays. Clin. Chim. Acta.; 376: 88-95.

69. Laurberg P. and et al., (2010). Iodine intake as a determinant of thyroid disorders in population. Best Pract. Res. Clin. Endocrinol. Metab.; 24: 13-27.

70. Pedersen L.I.B., (2007). Measurements of TSH receptor antibodies in differential diagnosis. Ligand Assay; 12(1): 62-65.

71. Planck T., (2010). Molecular Etiology of Graves; Disease and associated Opthalmopathy. Academic Dissertation Thesis; The medical faculty of Lund Univercity: 13-49.

72. Prummel M.F., Strieder T. and Wiersinga W.M., (2004). The environment and autoimmune thyroid diseases. Eur. J. Endocrinol.; 150: 605-618.

73. Rapoport B, Chazenbalk GD , Jaume JC, McLachlan SM. The thyrotropin (TSH) receptor: interaction with TS H and autoantibodies. Endocr Rev. 1998 Dec; 19(6):673-716. Review. No abstract avai lab Ie. Erratum in: Endocr Rev. 1999 Feb;20(1):100.

74. Rapoport B. and McLachlan S.M.,[eds], (2015). Graves' disease. A Comprehensive Guide for Clinicians; Chapter 2: 5-20.

75. Rapoport B., Chazenbalk G.D., Jaume J.C. and McLachlan S.M., (1998). The thyrotropin receptor: interaction with thyrotropin and autoantibodies. Endocr. Rev.;19: 673-716.

76. Rebuffat S.A., Nguyen B., Robert B., Castex F. and Peraldi R.S., (2008). Antithyroperoxidase antibody-dependent cytotoxicity in autoimmune thyroid disease. J. Clin. Endocrinol. Metab.; 93: 929-34.

77. Riley J.L. and June C.H. (2005). The CD28 family: a T-cell rheostat for therapeutic control of Tcell activation. Blood; 105: 13-21.

78. Ruf J., Czarnocka B., Ferrand M. and el al., (1988). Relationship between immunological structure and biochemical properties of human thyroid peroxidase. Endocrinol.; 125(3): 1211-1218.

79. Sahin M., Erdogan M.F. and Erdogan G., (2005). Cytotoxic T lymphocyte-associated molecule-4 polymorphisms in Turkish Graves' disease patients and association with probability of remission after antithyroid therapy. Eur. J. Intern. Med.; 16(5): 352-5.

80. Sanders J., Evans M., Premawardhana L.D., Depraetere H., Jeffreys J. and et al., (2003). Human monoclonal thyroid stimulating autoantibody. Lancet; 362: 126-128. 
81. Sanders J., Miguel R.N., Bolton J. and et al., (2007). Molecular interactions between the TSH receptor and a thyroid-stimulating monoclonal autoantibody. Thyroid; 17(8): 699-706.

82. Sanders J., Evans M., Premawardhana L.D., Depraetere H., Jeffreys J. and et al., (2003). Human monoclonal thyroid stimulating autoantibody. Lancet; 362: 126-128.

83. Saranac L., Zivanovic S., Bjelakovic B., Stamenkovic H., Novak M. and Kamenov B., (2011). Why Is the Thyroid So Prone to Autoimmune Disease? Horm. Res. Paediatr.; 75:157-165.

84. Sarfati M., Fournier S., Wu C.Y. and Delespesse G. (1992). Expression, regulation and function of human Fc epsilon RII (CD23) antigen. Immunol. Res.; 11: 260-72.

85. Sawai Y.Y. and DeGroot L.J., (2000). Binding of human thyrotropin receptor peptides to a Graves' disease predisposing human leukocyte antigen class II molecule. J. Clin. Endocrinol. Metab.; 85(3): $1176-1179$.

86. Sawicka-Gutaj N., Gutaj P., Sowiński J., Wender-Ożegowska E., Czarnywojtek A., Brązert J. and Ruchała M., (2014). Influence of cigarette smoking on thyroid gland -an update. Endokrynol. Pol.; 65 (1): 54-62.

87. Sayinalp S., Akalin S., Saynalp N., Erbas T., Bayraktar M. and et al., (1996). Serum immunoglobulin E and soluble CD23 in patients with Graves' disease. Hor. Metab. Res.; 28:133-137.

88. Schneider H., Downey J., Smith A., Zinselmeyer B.H., Rush C., Brewer J. M. and et al., (2006). Reversal of the TCR stop signal by CTLA-4. Sci; 313: 1972-1975.

89. Schott M. and Scherbaum W.A., (2006). Autoimmune thyroid disease. Med. J. of Dtsch. Arztebl.; 103(45): A 3023-32.

90. SI X., Zhang X., Tang W. and Luo Y., (2012). Association between the CTLA-4 +49A/G polymorphism and Graves' disease: A meta-analysis. Exp. Ther. Med.; 4(3): 538-544.

91. Silva L.M., Chavej J., Canalli M.H. and Zanetti C.R., (2003). Determination of IgG sub classes and avidity of antithyroid peroxidase antibodies in patients with subclinical hypothyroidism - a comparison with patient with overt hypothyroidism. Horm. Res.; 59(3): 118-24.

92. Silva L.M., Chavej J., Canalli M.H. and Zanetti C.R., (2003). Determination of IgG sub classes and avidity of antithyroid peroxidase antibodies in patients with subclinical hypothyroidism - a comparison with patient with overt hypothyroidism. Horm. Res.; 59(3): 118-24.

93. Simmonds M.J. and Gough S.C.L., (2005). Genetic insights into disease mechanisms of autoimmunity. Br. Med. Bull.; 71 (1): 93-113.

94. Simmonds M.J., Howson J.M., Heward J.M., Carr-Smith J., Franklyn J.A., Todd J.A. and Gough S.C., (2007). A novel and major association of HLA-C in Graves' disease that eclipses the classical HLA-DRB1 effect. Hum. Mol. Genet.; 16: 2149-2153.

95. Simmonds M.J., Howson J.M., Heward J.M., Cordell H.J., Foxall H., Carr-Smith J. and et al., (2005). Regression mapping of association between the human leukocyte antigen region and Graves' disease. Am. J. Hum. Genet.; 76: 157-163.

96. Singh A., (2009). Role of Pathogenic Mediators in murine Arthritis and Levels of Serum Soluble CD21 and CD23 in autoimmune patients. Mathematisch-NaturwissenschaftlicheFakultät; Rheinische Friedrich-Wilhelms-Universität Bonn: Delhi, India.

97. Soldin O.P., Chung S.H., and Colie C., (2013). The Use of TSH in Determining Thyroid Disease: How Does It Impact the Practice of Medicine in Pregnancy? J. Thyroid Res.; Vol. 2013: 1-8.

98. Spencer C.A., Hollowell J.G., Kazarosyan M. and Braverman L.E., (2007). National Health and Nutrition Examination Survey III thyroid-stimulating hormone (TSH)-thyroperoxidase antibody relationships

99. Sprent J. and Kishimoto H., (2001). The thymus and central tolerance. Transplantation; 72: 25-28. 
100. Stan M.N. and Bahn R.S., (2010). Risk factors for development or deterioration of Graves' ophthalmopathy. Thyroid; 20: 777.

101. Stassi G., Di Liberto D., Todaro M. and et al., (2000). Control of target cell survival in thyroid autoimmunity by $\mathrm{T}$ helper cytokines via regulation of apoptotic proteins. Nat. Immunol.; 1: 483.

102. Stassi G., Todaro M., Bucchieri F., Stoppacciaro A., Farina F., Zummo G., Testi R., De Maria R., (1999). Fas/Fas ligand-driven T cell apoptosis as a consequence of ineffective thyroid immunoprivilege in Hashimoto's thyroiditis. J. Immunol.; 162: 263-267.

103. Strieder, T.G. and et al., (2003). Risk factors for and prevalence of thyroid disorders in a cross-sectional study among healthy female relatives of patients with autoimmune thyroid disease. Clin. Endocrinol. (Oxf.); 59: 396-401.

104. Swain M., Swain T. and Mohanty B.K., (2005). Autoimmune thyroid disease- an update. Ind. J. Clin. Bioch.; 20(1): 9-17.

105. Takasu N. and Matsushita M., (2012). Changes of TSH-Stimulation Blocking Antibody (TSBAb) and Thyroid Stimulating Antibody (TSAb) Over 10 Years in 34 TSBAb-Positive Patients with Hypothyroidism and in 98 TSAb-Positive Graves' Patients with Hyperthyroidism: Reevaluation of TSBAb and TSAb in TSH-Receptor-Antibody (TRAb)-Positive Patients. J. of Thyroid Res.; Vol. 2012: 11 pages.

106. Weetman AP, McGregor AM. Autoimmune thyroid disease: developments in our understanding. Endocr Rev. 1984 Spring;5(2):309-55.

107. 733 thyroid peroxidase autoantibody epitopic “fingerprints'. J. Clin. Endocrinol. Metab.; 84: 1424-1431.

108. by American Association of Clinical Endocrinologists and the American Thyroid Association. Endocr. Pract.; 18: 1-207.

109. demonstrate that TSH upper reference limits may be skewed by occult thyroid dysfunction. $J$. Clin. Endocrinol. Metab.; 92: 4236-4240.

110. Graves' disease aberrantly express the IGF-1 receptor. J. Immunol.; 181(8): 5768-5774.

111. Wiersinga W.M., Drexhage H.A., Weetman A.P. and et al., (eds), (2006). The Thyroid and Autoimmunity. Merck European Thyroid Symposium Noordwijk ; 15-18. Stuttgart, Thieme.; 60-73.

112. Wiersinga W.M., Drexhage H.A., Weetman A.P. and et al., (eds), (2006). The Thyroid and Autoimmunity. Merck European Thyroid Symposium Noordwijk ; 15-18. Stuttgart, Thieme.; 60-73.

113. Pham W.K., Jung M.H., Choi E.J., Choi H.B., Kim T.G. and Suh B.K., (2011). Association of HLA Alleles with Autoimmune Thyroid Disease in Korean children. Horm. Res. Paediatr.; 76(5): 328-34.

114. Hammerstad S.S. and Tomer Y., (2015). Graves' disease. A Comprehensive Guide for Clinicians; Chapter 3: 21-37.

115. Okosieme O.E., Taylor R.C., Ohwovoriole A.E., Parkes A.B. and Lazarus J.H., (2007).

116. Prevalence of thyroid antibodies in Nigerian patients. QJM.; 100(2): 107-12.

117. Kandi S., Rao P., (2012). Anti-thyroid peroxidase antibodies: Its effect on thyroid gland and breast tissue. Editorial Commentary; 5(1): 1-2.

118. Garber J.R., Cobin R.H., Gharib H., Hennessey J.V., Klein I., Mechanick J.I., Pessah-Pollack R., Singer P.A. and Woeber K.A., (2012). Clinical Practice Guidelines for Hypothyroidism in Adults. 